interested in Indian cultural studies, Lord Zetland, who was in the chair, was able to reassure his audience. The risk, he said, that the collections of the India Museum might be dispersed, is at an end; and indeed, there is a prospect that the Indian sculptures at the British Museum (Bloomsbury) may be transferred to the India Museum at South Kensington.

THE discussion was an indication, if such were needed, of the existence of a strong body of instructed public opinion, restricted though it may be in extent, that a remedy must be sought for the present highly unsatisfactory position of Indian cultural studies. That there is need for an organized centre devoted to them may be argued on the ground of public policy in view of the future relations of Great Britain and India ; but it is also at the moment in pressing need of educational facilities in London. Contrary to the contention frequently advanced, $\mathbf{M r}$. Richards, from his experience as an honorary lecturer on Indian archæology in the University of London of some years' standing, was able to testify to the demand for instruction in this group of subjects; while the gratitude with which the rearrangement of the Indian collections at South Kensington on cultural lines has been acclaimed is a measure of the general appreciation of the possibilities of further systematic development in teaching and research. Whether provision of an organized centre of teaching and research can most suitably be made in connexion with the India Museum on the lines suggested in relation with the University of London is a matter for further consideration. The position of the Victoria and Albert Museum, of which the India Museum is at present a part, under the Board of Education, is anomalous. It presents difficulties, not insuperable, no doubt, which render comparison with other museums exercising teaching functions beside the mark, even though here, as in other of the national collections in London, the system of guide-lecturers exists for instructional purposes. This system might well be extended to meet needs of more advanced instruc. tion. In any event, no scheme of instruction can attain efficiency without the closest association with the collections and staff of the India Museum; nowhere else in Great Britain is there the systematic knowledge and the carefully graded series of specimens, for example, in pottery or beads, which may not be sufficiently spectacular for exhibition in public galleries, but are of the indispensable groundwork in instruction.

\section{Mr. E. Thurlow Leeds}

Mr. Edward Thurlow Leeds, keeper of the Ashmolean and the Department of Antiquities in the University of Oxford, whose election to a professorial fellowship at Brasenose College is announced, holds a position of distinction among archæologists for his carefully documented studies in Celtic and Saxon art and archæology. Mr. Leeds was educated at Uppingham and Magdalene College, Cambridge, on which foundation he was a scholar. $\mathrm{He}$ joined the staff of the Ashmolean as an assistant in the Department of Antiquities in 1908. Since the Great War, Mr.
Leeds's influence on the teaching of archæology at Oxford has been profound; and his appointment as keeper of the Ashmolean on the death of Dr. D. G. Hogarth was regarded as both opportune and a wellmerited recognition of his efforts in developing these studies in the University. Mr. Leeds was a vicepresident of the Society of Antiquaries of London in 1929-32 and Rhind lecturer in archæology in 1935, his lecture on "Early Saxon Art and Archæology" afterwards appearing in book-form. Mr. Leeds's responsibilities as keeper are now to be enlarged by the addition of an Institute of Egyptological Studies to the Museum. This is in accordance with a decree passed in Congregation of the University on November 29, which gives practical effect to the bequest, accepted in January last, by the late Prof. F. Ll. Griffiths, professor of Egyptology in the University of Oxford, and Mrs. Griffiths for that purpose. Although the Institute will form a department of the Ashmolean, it will be under the control of its own committee of management, a representative body.

\section{The Scientist and the Philosopher}

For his Friday evening discourse at the Royal Institution on December 2, Viscount Samuel took as his subject, "The Scientist and the Philosopher". $\mathrm{He}$ said that in the complicated civilization of the modern world a division of labour is necessary, but this is sometimes carried to excess. The separation between science and philosophy gives an example. This is not, as it might seem, a merely abstract and academic matter, remote from affairs. Action is ruled by ideas. Philosophies of some kind move the nations. Every land resounds with the tramp of armies, and the air throbs with the droning of their aircraft. Behind the armies are the dictators or the parliaments. Behind them are the political creeds, and behind the creeds are the philosophers who inspired them. Our age needs above all else a new synthesis of science and philosophy, together with religion, to supply the ideas that should guide the modern world. There are many things that philosophy should accept from science. Scientific workers in their turn may derive help from philosophy. They might be induced not to attribute physical qualities to human mental concepts, such as space; nor to assume that, because phenomena are out of reach of our means of observation, it follows that Nature does not determine them according to uniform laws. Two fundamental questions remain unsolved, and philosophers await the answers-from physics, the cause of gravitation, and from physiology the nature of thought. It is often said that these can never be solved; but if we view what has been the progress of knowledge between the stone age and now, further advances such as these are not inconceivable; they may indeed be close at hand. There is nowadays a marked convergence of science and philosophy. Let this develop and let religion, guided by reason and conforming to fact, take her place in the great synthesis; then man will feel at one with himself, will confront with new energy the confusions and perils that beset him, and be able to march with confident step into the future. 